\title{
Development and validation of an environmental DNA test for the endangered Gouldian finch
}

\author{
Kimberley Day ${ }^{1}$, Hamish Campbell ${ }^{1}$, Alaric Fisher ${ }^{2}$, Karen Gibb ${ }^{1, *}$, Brydie Hill ${ }^{2}$, \\ Alea Rose ${ }^{1}$, Simon N. Jarman ${ }^{3}$
}

\begin{abstract}
${ }^{1}$ Research Institute for the Environment and Livelihoods, Charles Darwin University, NT 0909, Australia
${ }^{2}$ Department of Environment and Natural Resources, Northern Territory Government, NT 0831, Australia ${ }^{3}$ School of Biological Sciences, University of Western Australia, WA 6009, Australia
\end{abstract}

\begin{abstract}
Detecting animals by identifying their DNA in water is a valuable tool for locating and monitoring species that are difficult to detect through other survey techniques. We developed a test for detecting the endangered Gouldian finch Erythrura gouldiae, a small bird endemic to northern Australia. Only 1 previous study has reported an environmental DNA (eDNA) test that unequivocally identifies a bird species using the water bodies from which they drink. In controlled aviary trials with a pair of Gouldian finches, first detection in $200 \mathrm{ml}$ of water occurred after as little as $6 \mathrm{~h}$, but the detection rate was higher at $30 \mathrm{~h}$. DNA persisted in water exposed to the sun for $<12 \mathrm{~h}$ and in the shade for $12 \mathrm{~h}$. In trials with 55 finches, persistence was up to $144 \mathrm{~h}$. The eDNA test for finches and the Gouldian finch-specific test were positive for waterholes where Gouldian and other finch species were observed each morning over $3 \mathrm{~d}$. Importantly, where no Gouldian finches were observed for up to $72 \mathrm{~h}$ prior to water sampling, the Gouldian test was negative. Where other species of finch but no Gouldian finch were observed and counted, the finch test was positive, but the Gouldian finch test was negative. This approach could be developed for broadscale monitoring of this endangered species, and potentially applied to a much broader range of terrestrial species that shed DNA into water bodies.
\end{abstract}

KEY WORDS: Birds · Distribution - eDNA · Filter · qPCR · Water · Gouldian finch • Erythrura gouldiae

\section{INTRODUCTION}

Bodies of fresh water are a useful resource for studies of vertebrate presence, absence and overall distribution inferred by detection of their DNA (Deiner et al. 2015, Fukumoto et al. 2015). The use of environmental DNA (eDNA) for detection of individual species has been applied to many aquatic animals such as amphibians (Fukumoto et al. 2015), reptiles (Piaggio et al. 2014), fish (Thomas et al. 2016) and insects (Furlan \& Gleeson 2017). The detection of nonaquatic vertebrates requires a pathway for DNA to be shed into the water. Cells or extracellular DNA deposited when drinking or defecating can in theory be used to identify animal presence at or near water

${ }^{*}$ Corresponding author: karen.gibb@cdu.edu.au

${ }^{\mp}$ Except for first and last authors, order is alphabetical bodies. There is some evidence that the presence of terrestrial mammals can be determined by sampling the water bodies from which they drink (Ushio et al. 2017). Only 1 study on eDNA detection of live, nonaquatic birds from water has been published to date (Ushio et al. 2018).

The Gouldian finch Erythrura gouldiae is a brightly coloured passerine bird in the family Estrildidae (Tidemann 1996, Bolton et al. 2016). The species has a broad and discontinuous distribution across the savannah woodland of northern Australia (Fig. 1) from Cape York to the western Kimberley region (O'Malley 2006). The Gouldian finch is currently listed as 'endangered' in Australia (Environment Protection and Biodiversity Conservation Act of 1999)

๑ T The authors 2019. Open Access under Creative Commons by Attribution Licence. Use, distribution and reproduction are unrestricted. Authors and original publication must be credited. 


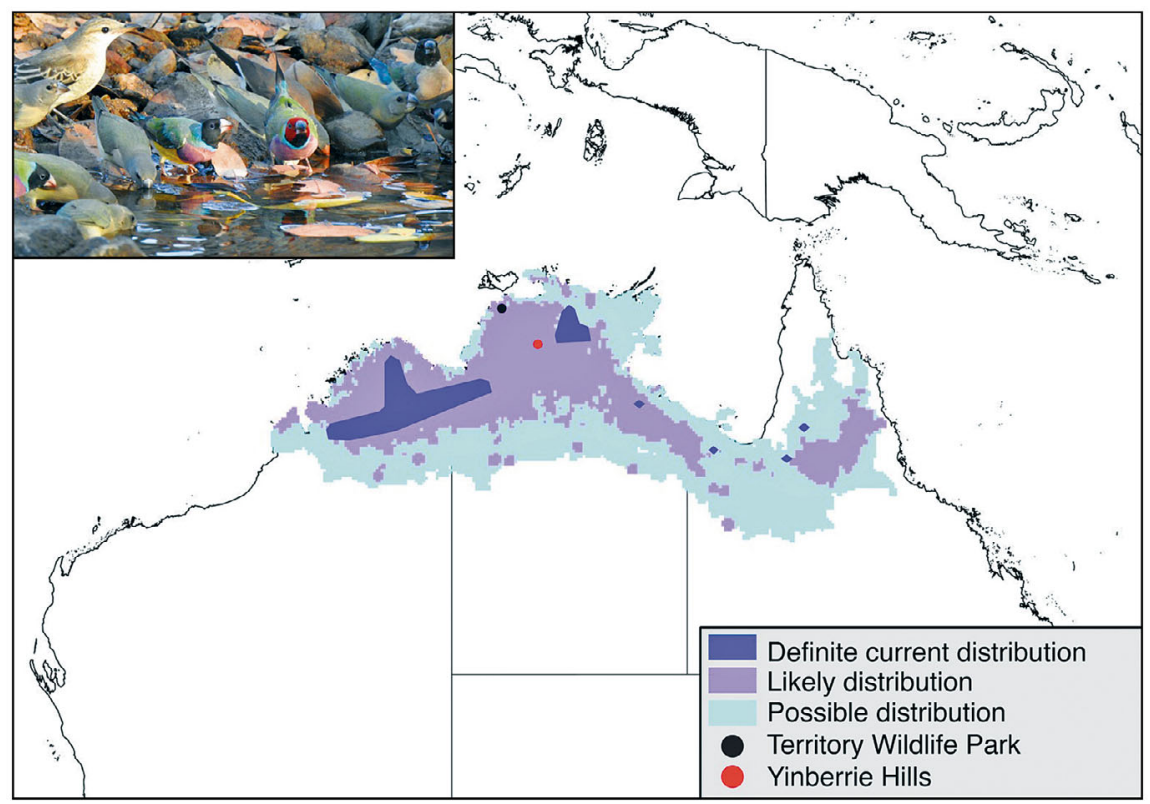

Fig. 1. Distribution of Erythrura gouldiae in northern Australia (Atlas of Living Australia, download at www.ala.org.au) with an inset picture of birds drinking from surface water. Photo: Alexander and Eckhard Garve, Germany due to habitat loss and degradation across its range (Dostine et al. 2001, O'Malley 2006). The International Union for the Conservation of Nature lists E. gouldiae as Near Threatened (Rodrigues et al. 2006). Current methods for detection and monitoring the Gouldian finch are fairly resource intensive and impractical to apply across the entire population.

The Gouldian finch is an ideal candidate for testing eDNA detection of a terrestrial species in water. Their primarily granivorous diet requires finches to drink water on a daily basis, providing a pathway for DNA to shed into the environment. During the late dry season in the monsoonal tropics, the release of Gouldian finch DNA into drinking water becomes more concentrated as waterholes suitable for drinking become rare (Evans et al. 1985). Mixed bird flocks drinking at such waterholes often also include long-tailed finch Poephila acuticauda and masked finch $P$. personata, as well as other members of the Estrildidae. Therefore, the eDNA test for Gouldian finches needs to be specific enough to differentiate between these closely related species.

Quantitative PCR (qPCR) assays have been demonstrated as a sensitive approach for detection of animals from eDNA (Thomsen \& Willerslev 2015). The qPCR assay system we designed uses a groupspecific PCR primer set to amplify a fragment of mitochondrial DNA from birds in the family Estrildidae and other close relatives. The sequence of this amplicon is variable among species, but contains a short region that is specific to the Gouldian finch. We designed a hydrolysis probe for this region that allows detection of Gouldian finch DNA, but not
DNA from close relatives that are sympatric with the Gouldian finch. This hybrid group-specific PCR detection system also allows for the use of spike-in positive control DNA (Furlan \& Gleeson 2017). This system for detecting Gouldian finch DNA is very effective for this species and provides an example of a robust PCR-based assay for eDNA with effective internal positive controls and a carefully established detection sensitivity.

We describe the development of this detection system in detail. We used controlled conditions in a captive environment (aviary) to trial and refine protocols for water sampling in the field. We report the effectiveness of the approach to detect Gouldian finch eDNA in a wild/natural environment.

\section{MATERIALS AND METHODS}

\subsection{Library construction, sequencing and isolation of sequences of interest}

Total DNA was purified from the blood of 3 finch species (Gouldian, long-tailed and masked) with a DNeasy Blood and Tissue DNA extraction kit (Qiagen). The DNA was used for Illumina library construction and sequenced in $150 \mathrm{bp}$ uni-directional reads on a NovaSeq platform (NovaSeq6000, $2 \times 150$ bp flowcell, SP chemistry; Ramaciotti Centre, Sydney, Australia). Three individuals from each species were analysed to make a total of 9 libraries. Two regions of interest were extracted from the pools of shotgunsequenced finch DNA: the nuclear ribosomal DNA 
gene regions and the mitochondrial DNA control region. These regions were identified in the libraries by choosing a reference sequence from a near relative and aligning reads on it with Bowtie2 (Langmead \& Salzberg 2012). The reference sequences for the nuclear ribosomal DNA region were from Goura cristata (GenBank MG590307.1) and for the control region from the zebra finch Taeniopygia guttata (GenBank DQ43515.1). Contigs were generated from the sequences that aligned with the reference sequences using Spades (Bankevich et al. 2012). Homologous contigs were then aligned with ClustalX for visualisation and primer design (Thompson et al. 2002)

\subsection{Amplification PCR primer design}

Primer-binding sites were manually selected from the aligned sequences for each region. Candidate pairs primer of binding regions were tested in OligoCalc (http://biotools.nubic.northwestern.edu/Oligo Calc.html) for primers with compatible annealing temperatures and lack of self-complementarity (Kibbe 2007). Each primer-binding site was tested by BLASTn (Altschul et al. 1990) against the current non-redundant database from GenBank to identify any potential sequence variants that would affect primer binding. Amplification primer-binding sites were chosen that were specific to Estrildidae finches, including Erythrura and Poephila, and in a groupspecific approach would produce a small enough PCR fragment for degraded DNA templates (Deagle et al. 2006) that had species-specific sequences within it (Jarman et al. 2004). This approach reduces the chance of false negative amplifications if Gouldian finch individuals had mutations in the primerbinding sites. Amplification primers (Table 1) and the Gouldian finch probe were synthesised by IDT Technologies.

Table 1. DNA sequences for the Gouldian finch Erythrura gouldiae eDNA detection assay. HEX and TET fluorescent 5' modifications are quenched by the Iowa Dark quencher (IDQ) when the probe is not digested by Taq polymerase. In contrast, the probe is digested and fluorescence occurs when it binds to target E. gouldiae sequence present in a positive test. All sequences are presented in the $5^{\prime}-3^{\prime}$ orientation

\begin{tabular}{|c|c|}
\hline DNA region & Sequence \\
\hline $\begin{array}{l}\text { E. gouldiae control region fragment. } \\
\text { Identical to GenBank KX858952.1, KX858951.1, } \\
\text { EF094912.1 }\end{array}$ & $\begin{array}{l}\text { TCA GGT ACC ATA CAG CCC AAG TGA TCC TAC CTC CGG CCA } \\
\text { GAG CCG CAA GCG TCA CCC GTA ATG CTA GGG ACT TAT CTA } \\
\text { TTG TAC TTA CTC CTT AAC CTG GGA AAC GAC TAA TGT CAC } \\
\text { AGT ACT CCT TTG CAT TCC TAA GGT CTA TGG AAT TCG CCC } \\
\text { ACC TCC TAG G }\end{array}$ \\
\hline $\begin{array}{l}\text { Poephila acuticauda control region fragment. } \\
\text { Identical to GenBank JQ255410.1, JQ255410.1 }\end{array}$ & $\begin{array}{l}\text { TCA GGT ACC ATA TAG CCC AAG TGA TCC TAC CTA CAG GCC } \\
\text { GAG CCG CAA GCG TCA CCC ACA CAC ATA GGA ACT TTC CAT } \\
\text { TGT ACT AAA CCC CCA ACC CAG GAA ACG AGG AGT GTT ACT } \\
\text { GTA CAC CTT TGC ATT CTC AAA GTC TAC TGA ATT CGC CCA } \\
\text { CCT CCT AGG }\end{array}$ \\
\hline Poephila personata control region fragment & $\begin{array}{l}\text { TCA GGT ACC ATA TAG CCC AAG TGA TCC TAC CTA CAG GTC } \\
\text { GAG CCG CAA GCG TCA CCC ACA CAC ATA GGA ACT TTC CAT } \\
\text { TAT ACT AAA CTC TCA ACC CAG GAA ACG AGG AGT GTT ACT } \\
\text { GTA CAC CTT TGT ATT CTC AAA GTC TAC TGA ATT CGC CCA } \\
\text { CCT CCT AGG }\end{array}$ \\
\hline Synthetic positive assay control & $\begin{array}{l}\text { CAG ACA ACA TTC AGG TAC CAT ACA GCC CAA AAG TCT TTC } \\
\text { CCT CTT TCG CGT CAT GCC GCT GGG GAA TCC CAA ATA TCC } \\
\text { GCA AAT ATG GAG GCG ACG GTC TAA TCC TCC TTT CCG AAC } \\
\text { CCC CCG CAT TCT CCT TCA GAT TTT CAT GGA ATT CGC CCA } \\
\text { CCT CCT AGG CTC GCT AGA C }\end{array}$ \\
\hline $\begin{array}{l}\text { FinchCR_F1 } \\
\text { Finch control region forward primer }\end{array}$ & TCA GGT ACC ATA YAG CCC AA \\
\hline $\begin{array}{l}\text { FinchCR_R1 } \\
\text { Finch control region reverse primer }\end{array}$ & CCT AGG AGG TGG GCG AAT TC \\
\hline $\begin{array}{l}\text { Gouldian finch probe } \\
\text { E. gouldiae internal hydrolysis probe }\end{array}$ & HEX-CGT CAC CCG TAA TGC TAG GGA-IDQ \\
\hline $\begin{array}{l}\text { DNA positive probe } \\
\text { Synthetic positive control internal hydrolysis probe }\end{array}$ & TET-GTC TAA TCC TCC TTT CCG AAC C-IDQ \\
\hline
\end{tabular}




\subsection{Design of a species-specific probe}

A hydrolysis probe was designed to identify amplicons that came only from the Gouldian finch. The sequence for the probe was identified from an alignment of the nuclear control region of sequence data from the 3 species of finch. We also searched GenBank for sequences from related finches. This search produced 38 hits for the Gouldian finch which were produced in a previous population genetics study (Bolton et al. 2016). The hydrolysis probe was labelled with the fluorophore HEX at the $5^{\prime}$ end and the Iowa Dark quencher at the 3' end (Table 1). Amplification primers and probes were tested for specificity to group or species by BLASTn searches of GenBank (Altschul et al. 1990).

\subsection{Design of an internal positive control synthetic DNA fragment}

A fragment of synthetic DNA was synthesised (IDT Technology) for use as an internal positive control for the PCR amplification of environmental DNA (Furlan \& Gleeson 2017). The GC\% of the Gouldian finch DNA was determined, and randomly generated fragments of DNA with similar GC\% and length were assessed by BLASTn (Altschul et al. 1990) searches of GenBank to ensure that they had no unintended homology to any known organisms that might also be present in eDNA.

\subsection{Water sampling and eDNA purification}

Water samples $(200 \mathrm{ml})$ were collected from water bodies with sterile Nalgene bottles. The water was filtered through sterile, $0.45 \mu \mathrm{M}$, mixed cellulose ester filters (Merck Millipore). DNA was purified from the filters using a DNeasy Blood and Tissue DNA extraction kit (Qiagen). Samples were extracted according to the manufacturer's guidelines for tissue (step 1a) with some modifications. Before extracting, filters were placed into sterile, $2 \mathrm{ml}$ freestanding screw tubes containing 4 sterile, $2 \mathrm{~mm}$ glass beads. Filters were pulverised into $2-3 \mathrm{~mm}$ fragments by immersing the tubes in liquid nitrogen and disrupting with a Mo Bio PowerLyser ${ }^{\mathrm{TM}} 24$ at $800 \times g$ for $30 \mathrm{~s}$. For each sample, the volumes of lysis and buffer solutions (Quiagen) were $60 \mu$ l Proteinase K, $540 \mu \mathrm{l}$ buffer ATL, $600 \mu \mathrm{l}$ buffer AL and $600 \mu \mathrm{l} 100 \%$ ethanol. During lysis, filters were incubated overnight at $56^{\circ} \mathrm{C}$ in a BIOLINE Shaker. Purified DNA was eluted in $200 \mu \mathrm{l}$ of $\mathrm{H}_{2} \mathrm{O}$. The yield and quality of extracted DNA was checked with a $1 \mu$ subsample using a NanoDrop 2000 (Thermo Scientific).

\subsection{Molecular sensitivity testing for the Gouldian finch DNA detection assay}

The number of Gouldian finch mitochondrial molecules that the assay could detect was quantified by diluting extracted Gouldian finch DNA over 8 orders of magnitude (from 100 picomoles to 10 attamoles) with $10 \mathrm{mM}$ Tris- $\mathrm{HCl} \mathrm{pH}$ 7.5. Purified Gouldian finch DNA was extracted from $10 \mu \mathrm{l}$ of nucleated blood using the DNeasy Blood and Tissue Kit. Each dilution was mixed with Quantitect SYBR Green (Qiagen) and $0.1 \times$ BSA, and then run in triplicate on a RotorGene ${ }^{\circledR} \mathrm{Q}$ (Qiagen).

\subsection{Test validation using captive birds}

Aviary trials were conducted at the Territory Wildlife Park (TWP), $45 \mathrm{~km}$ south of Darwin, Northern Territory. Trials were run to determine optimal sample volume, time until first detection, eDNA persistence, turbidity effects and species specificity. For each trial, $18 \mathrm{l}$ trays of tap water were exposed to either a single pair (2 individuals; aviary dimension $3 \times 1.2 \times 2 \mathrm{~m}^{3}$ ) or a large group (55 individuals; aviary dimension $8 \times 5 \times 3 \mathrm{~m}^{3}$ ) of Gouldian finches over 3 consecutive days. Each aviary was fitted with a surveillance camera to monitor interactions with the water tray. Each trial was repeated 3 times, and negative controls were collected at the start of each trial, with the exception of the specificity trial. Water trays were placed away from roosts to avoid droppings. Water samples were collected in triplicate using sterile gloves, syringes and bottles.

To determine the optimal sample volume, 20, 50, 100 and $200 \mathrm{ml}$ samples were collected after $3 \mathrm{~d}$ of exposure to a single pair of Gouldian finches. Cameras showed that the birds became active after 07:00 h, so trials started at 07:00 h. To measure first detection of eDNA from a single pair of Gouldian finches, $200 \mathrm{ml}$ samples were collected at $12: 30 \mathrm{~h}$ on the day of fresh water exposure, to represent half daily activity. A second sample was collected the following morning at 06:45 $\mathrm{h}$, before the birds became active, to capture the whole activity period of the previous day. Aviary waters were sampled at 12:30 and 06:45 h over 3 consecutive days of exposure to Gouldian finches. To measure persistence of eDNA, aviary water was transported from TWP to Charles Dar- 
win University (CDU) after $3 \mathrm{~d}$ of exposure to the large group of Gouldian finches. This water was placed in direct sunlight, and $200 \mathrm{ml}$ were collected in triplicate at 0,12 and $24 \mathrm{~h}$ (since commencement of trial) of the first day and every $24 \mathrm{~h}$ thereafter, until there was no more water. The trial was repeated for a single pair of Gouldian finches, with the addition of a shaded treatment (double layer of $80 \%$ shade cloth).

To test the effect of turbidity, sterilised sediment $(<63 \mu \mathrm{m})$ was used to simulate turbid conditions, and turbidity was measured with a Lovibond turbidimeter, in nephelometric turbidity units (NTU). Treatments were water (10 1 tap water and 51 homogenised aviary water) and turbid (as for water treatment but with sediment added to $100 \mathrm{NTU}$ ). Treatments were left in direct sunlight, and $200 \mathrm{ml}$ were collected in triplicate at 0,12 and $24 \mathrm{~h}$ (since commencement of trial) of the first day and every $24 \mathrm{~h}$ thereafter, until there was no more water. To test for inhibition from the turbid DNA samples, 2 positive samples comprising $1 \mu \mathrm{l}$ of Gouldian finch DNA from blood samples were spiked with $1 \mu \mathrm{l}$ of DNA extracted from the 'turbid' samples. To account for dilution, $1 \mu \mathrm{l}$ of high pure water was added to 2 other positive control blood samples.

Specificity was tested using water from 3 aviaries at the TWP that contained a range of bird species, including closely related sympatric species but no Gouldian finches. The aviaries were (1) Pandanus Creek, containing crimson finches Neochmia phaeton, (2) Paperbark Swamp, containing long-tailed finches and chestnut-breasted mannikins Lonchura castaneothorax and (3) Walk Through Aviary, containing a mix of other bird species but no finches of any species. Water samples were collected from the artificial pools in each aviary.

\subsection{Statistical tests}

To determine which factors significantly influenced eDNA detection, we applied permutational testing using Primer7 software (Anderson et al. 2008). To quantify similarities between samples, we used a Bray-Curtis similarity matrix (detection positive $=1$ and negative $=0$ ) and zero-adjusted (Clarke et al. 2006). Raw data were not transformed because the dataset consisted of 1 and 0 values only. Data were analysed using a PERMANOVA with 999 permutations. Results were considered significant at $\mathrm{p}<0.05$. Each experiment was analysed using 2 or 3 factors (see Table A1 in the Appendix for factor allocations). Briefly, experimental factors included aviary, volume, visits, sampling round, temperature and treat- ment. Turbidity and specificity experiments did not require statistical analyses because they were all negative and had small sample numbers, respectively.

\subsection{Test validation at waterholes}

Water was sampled as described above from small natural waterholes at the Yinberrie Hills $(45 \mathrm{~km}$ north of Katherine, Northern Territory), which supports the largest extant breeding population of Gouldian finches in the Northern Territory (Dostine et al. 2001). Waterholes were selected following a site visit in early September 2018 to assess access, water levels and use by birds. The aim was to sample 2 waterholes in each of 3 categories: high, moderate and no bird usage. Six waterholes were selected (see Table 3 for their locations and sampling dates). Birds were counted at each waterhole to provide an estimate of recent use by all finch species and to test the robustness of both the general finch and Gouldian-specific eDNA tests. The number of Gouldian, long-tailed and masked finches were counted at each waterhole between 07:00 and 10:00 h for 3 consecutive mornings and prior to sampling.

To determine whether local environmental conditions affected the probability of eDNA detection, water samples were collected from 3 locations within each waterhole. Three $200 \mathrm{ml}$ water samples were taken 'at' $(0 \mathrm{~m})$, 'near' ( 0.5 m) and 'far' ( 2 m) from where birds were observed drinking for each waterhole. Where no birds were observed drinking, sampling locations were taken from the edge most representative of a typical drinking point. Sampling included 1 negative control where a $250 \mathrm{ml}$ Nalgene bottle filled with high pure water was opened for $2 \mathrm{~min}$, closed and stored at $4^{\circ} \mathrm{C}$. At each site, we also collected 6 water samples (each $200 \mathrm{ml}$ ) for a $2 \mathrm{wk}$ storage trial at $4^{\circ} \mathrm{C}\left(3\right.$ samples site $\left.{ }^{-1}\right)$ and at room temperature ( 3 samples $s^{-1}{ }^{-1}$ ). This was done to assess robustness of the test when filtering equipment was not available in the field and samples had to be stored for an extended period before processing. Waterhole volume was estimated by measuring length, width and depth at multiple points using a tape measure.

\section{RESULTS}

\subsection{Shotgun DNA sequencing}

Between 1.2 and 1.45 million sequence reads were generated for each genome skimming library (Dods- 
worth 2015). Contigs were assembled for both the control region and internal transcribed spacer 2 (ITS2) regions for 3 individuals of each species of Gouldian, long-tailed and masked finches. Sequence variation in the control region contigs among all 3 species was identified and incorporated into primer designs by either avoiding the variable sites, or by using degenerate base sites to accommodate the identified variants.

\subsection{Gouldian finch eDNA qPCR detection assay validation}

The PCR-based detection system that we designed and tested for Gouldian finch environmental DNA is shown in Fig. 2. Amplification specificity was tested empirically at a range of different annealing temperatures from 45 to $60^{\circ} \mathrm{C}$. Amplification products were separated by electrophoresis at $5 \mathrm{~V} \mathrm{~cm}^{-1}$ on $2 \%$ agarose Tris-borate-EDTA gels and visualised by fluorescence at $\sim 520 \mathrm{~nm}$ of SYBR Safe (Molecular Probe) under $\sim 460 \mathrm{~nm}$ excitation. PCR products of the expected size were observed at all tested annealing temperatures for the control region primer pair. The ITS2 primer pair failed to amplify under these conditions, which is likely because of the very high
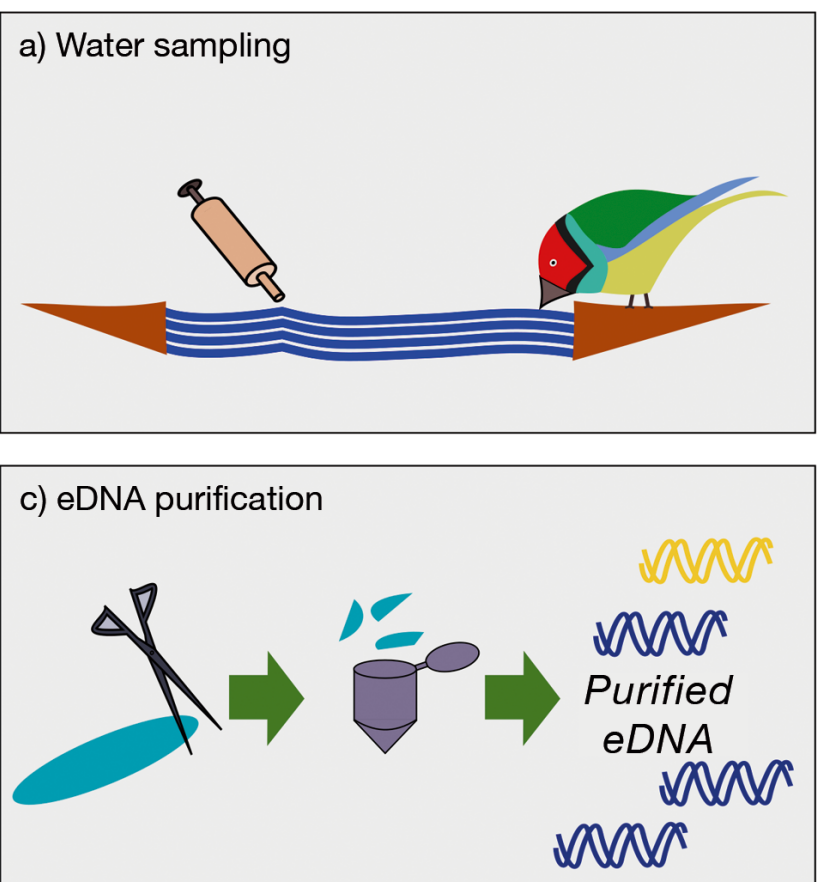

GC\% of the target region, and we subsequently abandoned development of this potential marker.

Thermal cycling conditions for the control region primer pair were optimised at $94^{\circ} \mathrm{C}$ for $20 \mathrm{~min}$; 45 cycles of $94^{\circ} \mathrm{C}$ for $10 \mathrm{~s}, 60^{\circ} \mathrm{C}$ for $30 \mathrm{~s}, 72^{\circ} \mathrm{C}$ for $30 \mathrm{~s}$ with optical data acquisition; and $72^{\circ} \mathrm{C}$ for $2 \mathrm{~min}$. Melt curves were tested for their ability to discriminate among amplicons from Gouldian, long-tailed and masked finches, but the melting profiles were too similar for reliable discrimination. Consequently, a hydrolysis probe was used instead to specifically detect the Gouldian finch. Addition of this probe to the mix produced a species-specific test for the Gouldian finch. The amplification primers and probe region were conserved in the sequences produced by Bolton et al. (2016), so we know that in 41 of 41 examined cases in silico, this assay would specifically identify Gouldian finch DNA. Empirical testing of this amplification primer set and probe combination on 3 individuals of each finch species tested only resulted in HEX fluorescence at $556 \mathrm{~nm}$ for Gouldian finch DNA. Further testing for amplification from multiple individuals revealed amplification in all 22 cases, suggesting that this test works consistently within the species. No HEX fluorescence was detected for 21 long-tailed or 5 masked finch DNA samples, although SYBR Green fluorescence was, indicating that the b) Sample filtration

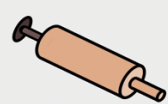
Mavp Synthetic positive o WON control DNA 10 WONON d) Quantitative PCR

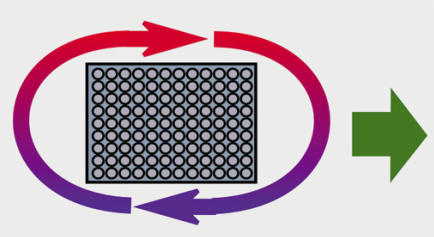

Thermal cycling

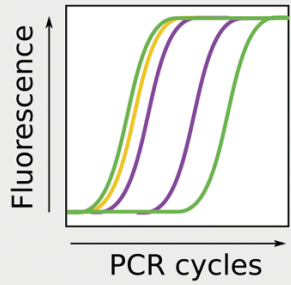

Fig. 2. Gouldian finch eDNA detection assay. Water body where the Gouldian finch might be present is (a) sampled and (b) filtered. Synthetic positive control DNA can be added so that false negative tests can be identified later. (c) eDNA is purified from the filters and (d) analysed by quantitative PCR 
group-specific primers amplified from these species. The different types of results that the test can produce are shown in Fig. 3.

The control region fragment of the Gouldian finch that we sequenced and amplified was $166 \mathrm{bp}$ long with a GC content of exactly $50 \%$. The synthetic positive spike-in control DNA that we synthesised also had a GC content of $50 \%$ and a randomly generated sequence between the primer-binding sites for primers FinchCR_F1 and FinchCR_R1 (Table 1). This was $186 \mathrm{bp}$ long because $10 \mathrm{bp}$ extensions were added to the 5' and 3' ends of the primer-binding sites to ensure that exonuclease activity did not affect the amplifiability of the fragment.

\section{a) True positive E. gouldiae}

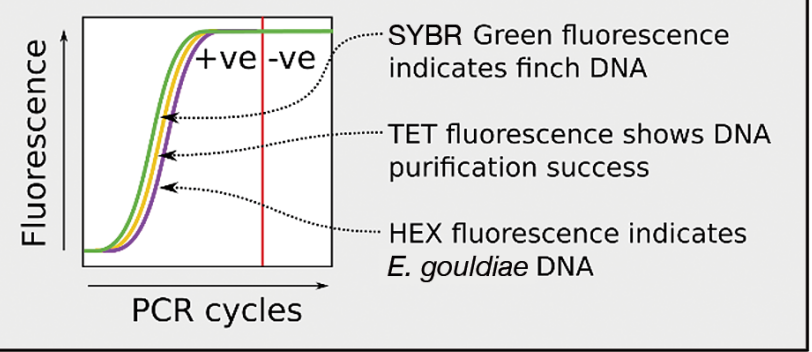

c) True positive non-E. gouldiae finch

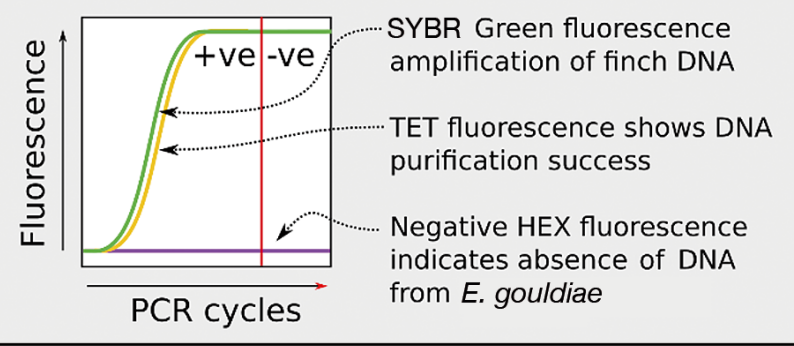

e) True negative E. gouldiae

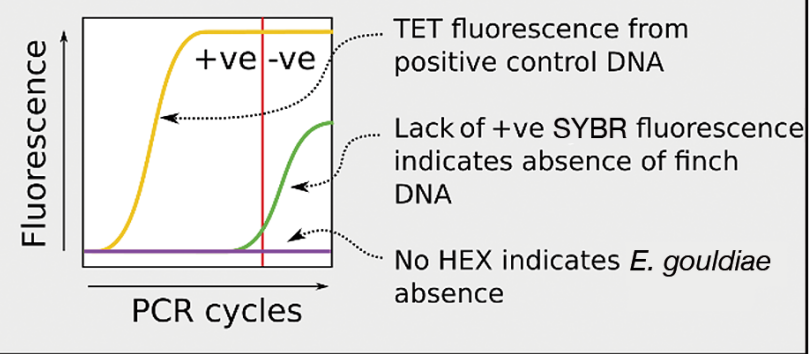

\subsection{Molecular sensitivity of the Gouldian finch DNA detection assay}

Our qPCR assay had a detection limit of 10 attamoles ( 300 molecules of 160 bp ds (double-stranded) DNA at $90 \mathrm{kD}$ ) of Gouldian finch control region DNA in a qPCR. This level of sensitivity is consistent with that reported for other qPCR assays (Ahrberg \& Neužil 2015).

\subsection{Gouldian finch detection in aviaries}

Gouldian finch eDNA was successfully detected in drinking water from aviaries using our test. The

\section{b) False positive E. gouldiae}

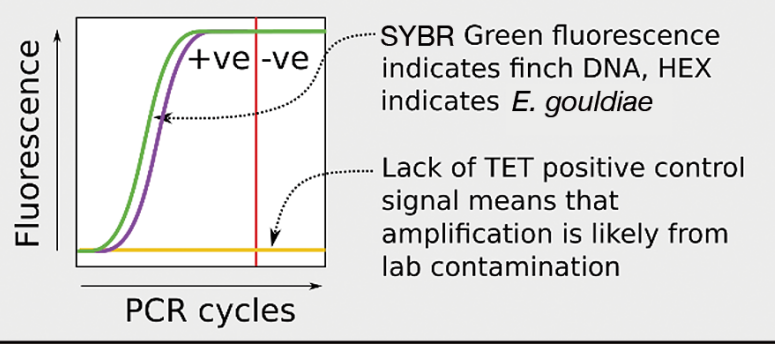

d) False positive non-E. gouldiae finch
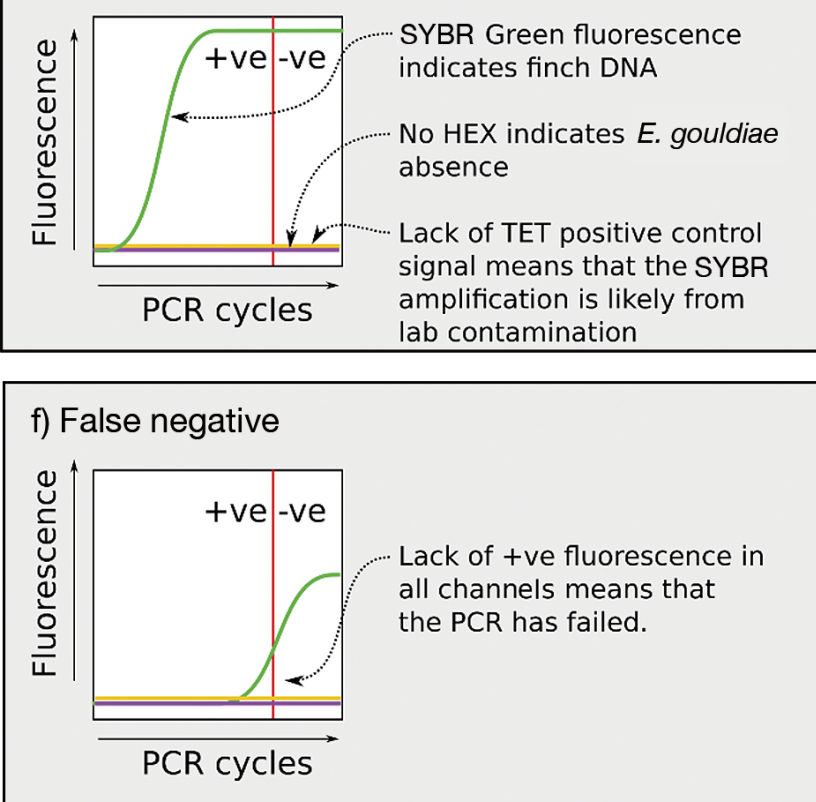

Fig. 3. Interpretation of quantitative PCR results from the Gouldian finch eDNA detection assay. A cycle threshold of 40 cycles (red vertical line) is used to differentiate between positive (+ve) and negative results (-ve). The test includes internal positive control DNA that can be identified through TET fluorescence, which helps to identify false negative and positive results. The Gouldian finch Erythrura gouldiae can be identified specifically by HEX, and Estrellidae finches can be identified by SYBR Green fluorescence. If desired, positive tests for these finches could be identified to species level by sequencing the amplicons produced by the qPCR. (a) True positive and (b) false positive E. gouldiae test; (c) true positive and (d) false positive nonGouldian finch test; (e) true negative E. gouldiae test; (f) false negative test 
volume which resulted in the greatest number of detections was $200 \mathrm{ml}$ $(\mathrm{p}=0.005)$, although all sample volumes, including $20 \mathrm{ml}$, had positive detections (Table 2). First detection was after $6 \mathrm{~h}$ of exposure in 1 singlepair aviary. By midday the following day ( $30 \mathrm{~h}$ of exposure), all aviaries had positive detections (Table 2). First detection may therefore occur as soon as $6 \mathrm{~h}$ or as late as $30 \mathrm{~h}$ following exposure.

Camera surveillance in aviaries showed that the finches drank from the water trays but did not bathe in them. Feathers and a small number of faeces were observed in the water trays, providing DNA from multiple sources. Water trays were visited 11 times $\mathrm{d}^{-1}$ on average in the singlepair aviaries and 238 times $\mathrm{d}^{-1}$ on average in the large (55 bird) group aviary. Detection was positively associated with 'visits' $(\mathrm{p}=0.001$; Table A1), as expected, since more visits increase the opportunity for DNA to be shed in the water. In the large group aviary, there was an effect of 'aviary' in each repetition of the trial; this is possibly because the birds became familiar with the new watering station and visited more often in the second and third trial run compared to the first $(p=0.001$; Table A1).

For single pairs of birds, the DNA persisted for $12 \mathrm{~h}$ under shaded conditions and $<12 \mathrm{~h}$ in direct sunlight. However, from the aviary containing 55 Gouldian finches, DNA persisted up to $144 \mathrm{~h}$ in direct sunlight. The turbid treatment samples were all negative, and the non-turbid (water) treatment samples were all positive (Table 2, showing time 0 only). The 4 positive control samples, 2 of which were spiked with DNA from the turbid water treatment, were positive, suggesting no inhibition (Chung 2004, Opel et al. 2010).

Water collected from the Pandanus Creek aviary, containing crimson finches, and Paperbark Swamp aviary, containing long-tailed finches and chestnutbreasted mannikins, were positive for the finch test but negative for the Gouldian test (Table 2). Walk Through Aviary, which contained a mix of bird species but no finches, was negative for both tests (Table 2).
Table 2. Aviary trials for detection of finch eDNA. The 9 samples refer to 3 replicates from each of 3 trials per test. For statistical significance values, see Table A1 in the Appendix

\begin{tabular}{|c|c|c|c|}
\hline Trial & Treatments & \multicolumn{2}{|c|}{$\begin{array}{c}\text { Gouldian finch test } \\
\text { no. positive / } 9\end{array}$} \\
\hline $\begin{array}{l}\text { Minimum sample } \\
\text { volume (ml) }\end{array}$ & $\begin{array}{l}200 \\
100 \\
20 \\
50\end{array}$ & & $\begin{array}{l}9 \\
8 \\
5 \\
5\end{array}$ \\
\hline $\begin{array}{l}\text { First detection } \\
\text { (h post exposure) }\end{array}$ & $\begin{array}{c}6 \\
9 \\
24 \\
30\end{array}$ & & $\begin{array}{l}1 \\
3 \\
2 \\
7\end{array}$ \\
\hline $\begin{array}{l}\text { Persistence in } \\
\text { sun ( } 55 \text { Gouldian } \\
\text { finches; } \mathrm{h})\end{array}$ & $\begin{array}{c}0,12 \\
24 \\
48 \\
72 \\
96,120,144 \\
168\end{array}$ & & $\begin{array}{l}9 \\
8 \\
4 \\
3 \\
1 \\
0\end{array}$ \\
\hline $\begin{array}{l}\text { Persistence in sun } \\
(2 \text { Gouldian finches; } \mathrm{h})\end{array}$ & $\begin{array}{c}0 \\
12\end{array}$ & \multicolumn{2}{|c|}{$\begin{array}{l}7 \\
0\end{array}$} \\
\hline $\begin{array}{l}\text { Persistence in shade } \\
(2 \text { Gouldian finches; } \mathrm{h})\end{array}$ & $\begin{array}{c}0 \\
12 \\
24\end{array}$ & \multicolumn{2}{|c|}{$\begin{array}{l}8 \\
1 \\
0\end{array}$} \\
\hline Water turbidity & $\begin{array}{c}\text { Turbid } \\
\text { Non turbid }\end{array}$ & \multicolumn{2}{|c|}{$\begin{array}{l}0 \\
9\end{array}$} \\
\hline Specificity & $\begin{array}{c}\text { Pandanus Creek } \\
\text { Paperbark Swamp } \\
\text { Walk Through Aviary }\end{array}$ & $\begin{array}{c}\text { Finch test } \\
3 / 3 \\
2 / 3 \\
0 / 3\end{array}$ & $\begin{array}{c}\text { Gouldian test } \\
0 / 3 \\
0 / 3 \\
0 / 3\end{array}$ \\
\hline
\end{tabular}

\subsection{Test validation at waterholes}

Non-specific finch and Gouldian finch eDNA was detected in natural waterholes at Yinberrie Hills (Table 3). At the 2 waterholes where no finches were observed (JC05 and Deadwomans 4), both the finch and Gouldian finch tests were negative. At 3 waterholes where birds had visited within $24 \mathrm{~h}$ of sampling (Poachers, JC10 and Deadwomans 2), the proportion of samples that were positive for the finch test were 100,89 and $33 \%$, respectively (Table 3 ), with the $33 \%$ result from a large (55000 l) waterhole. The proportion of samples that were positive for Gouldian finch at those same waterholes were 100, 44 and $0 \%$, respectively. At Deadwomans 1 waterhole where no Gouldian finches had visited within $48 \mathrm{~h}$, but other finch species had (in low numbers), the finch test had $11 \%$ positive samples and the Gouldian finch test had none.

Stored water samples from Poachers and JC10 waterholes that were positive when filtered on site were also positive for both the finch and Gouldian finch 


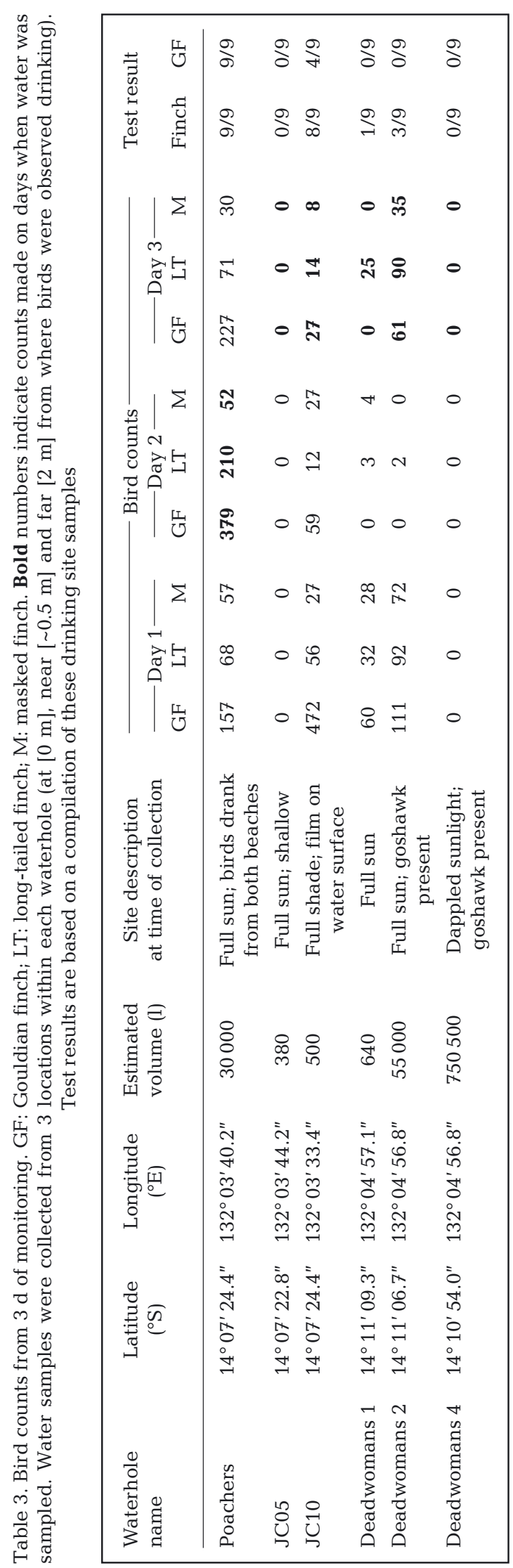

tests after storage for $14 \mathrm{~d}$, regardless of the storage temperature. At Deadwomans 2 waterhole which was $33 \%$ positive for the finch test and negative for the Gouldian finch test, all stored samples were negative. At JC05 and Deadwomans 4 waterholes which were negative for both on-site tests, there was a single positive for the finch test (from 3 samples), but the Gouldian finch test remained negative.

\section{DISCUSSION}

Environmental DNA analysis has become a valuable tool for studying animal distributions (Ushio et al. 2017). It is particularly valuable for detecting animals that are difficult to detect directly by other methods, due to being cryptic, rare, transitory, trapshy or occurring in environments that are difficult or dangerous to sample. The Gouldian finch is a highly mobile species that occurs sparsely over a large area. Obtaining adequate detection probabilities from standard visual census techniques, for either distribution assessment or population monitoring, is challenging, especially across broad geographic extents that are generally remote. However, as this species congregates at small waterholes to drink daily, detection of Gouldian finch presence by aquatic eDNA sampling may be an alternative, cost-effective survey technique. The test we have developed is a useful tool that will contribute to future assessment of the distribution of this species, and one which may be elaborated into a robust population monitoring method at important locations for the species, such as the Yinberrie Hills.

Molecular methods for eDNA analysis have been changing constantly for the past decade (Jarman et al. 2018). The design of our qPCR assay for Gouldian finch eDNA involved multiple channels of fluorescent detection (Ahrberg \& Neužil 2015) to provide a versatile test for the Gouldian finch and other finches. The group-specific approach for PCR amplification also lowers the chance of encountering a Gouldian finch with sequence variation in the PCR primer-binding sites leading to undetectable false negative outcomes. The test provides an opportunity to determine the presence of other finch species either by sequencing the PCR products, or by designing alternative hydrolysis probes for detecting them. The system also allows for a true internal positive control to be incorporated in the form of synthetic spike-in DNA and a hydrolysis probe for detecting it. This allows differentiation among true and false negative and positive results (Furlan \& Gleeson 2017). 
Aviary trial results provided the first indication that this test could detect finch and specifically Gouldian finch DNA in water which the birds had accessed a testament to its sensitivity and potential value for detecting terrestrial species in the wild. The volumes of water tested were small because the Gouldian finch generally drinks from small pools of surface water, so any field application of this method should be capable of identifying the birds where only small quantities of water are available. Detection was successful in as little as $20 \mathrm{ml}$, which was very encouraging. The positive association between frequency of visits to the water trays and positive test results is expected, because at each visit, more eDNA is shed (Williams et al. 2018). This result suggests there is potential to explore quantitative approaches to eDNA sampling in the future.

Although the presence of more birds was associated with a greater accumulation of DNA and greater persistence, turbidity and temperature could act as counterbalances. Addition of fine sediment negatively impacted finch DNA detection without impacting control amplifications. A variety of possible reasons for this exist, but we were unable to explain this result within the scope of this study. Adsorption of eDNA to fine soil particles confounds DNA extraction efficiency (Saeki \& Sakai 2009, Yu et al. 2013) and will need to be resolved in further optimisation studies (Williams et al. 2017).

The aviary trials also demonstrated specificity for finch and Gouldian finch DNA, and other speciesspecific eDNA assays that have taken a similar qPCR approach also reported high specificity (Thomsen et al. 2012, Takahara et al. 2013, Wilcox et al. 2013). A number of factors could influence the reliability of the eDNA tests, one of which is DNA persistence. Results from the aviary experiments indicated that with only 2 birds, the first detection could be as short as $6 \mathrm{~h}$ and the signal persisted for $12 \mathrm{~h}$, though less when water was left in the sun. However, with as many as 55 Gouldian finches, the DNA signal could persist for up to $144 \mathrm{~h}$ in the sun.

The eDNA tests we have developed for finches and Gouldian finch were successful when trialled in the field, using DNA extracted from as little as $200 \mathrm{ml}$ of water. The eDNA test for finches and the Gouldian finch-specific test were positive for waterholes where Gouldian and other finch species were observed each morning over $3 \mathrm{~d}$. Importantly, where no Gouldian finches were observed for up to $72 \mathrm{~h}$ prior to water sampling, the test was negative. The speciesspecificity of the Gouldian finch test developed in the lab was successful in the field and consistent with the aviary validation. Where other species of finch but no Gouldian finches were observed and counted, the finch test was positive, but the Gouldian finch test was negative. These results are very promising, considering the early stages of research on the use of eDNA for vertebrate detection in the field (Ushio et al. 2017, 2018). Although the test has high specificity and there were no false positive results, there were negative results for waterholes where Gouldian finches were present, indicating that the reliability and robustness of the tests still need optimisation.

In the waterhole trials, 1 site with 60 Gouldian finches recorded on the first day of surveys was negative for water collected on Day 3 after $2 \mathrm{~d}$ of no Gouldian finch visits, suggesting that persistence in the field environment may be shorter than that recorded in the aviaries. Further waterhole trials are required to derive average persistence, predicated on a set of environmental conditions, which will help inform the design and interpretation of monitoring surveys that use eDNA.

Waterholes provide a completely uncontrolled environment, very different from clean drinking water in aviaries. Natural waterholes contain enzymes that break down DNA and are exposed to sun which degrades DNA. They also contain algae and other bacteria which may break down, mask or promote (by providing a surface to adhere to) eDNA signals. While it may not be possible to control or determine the direct impact of these variables, it is important to clarify and at least attempt to increase the probability of detection to an acceptable level for each survey purpose. The aviary studies also showed that fine sediment will negatively affect DNA recovery. In the waterholes tested, the turbidity was low except at one of the control sites, so the impacts of turbidity in real field situations remains unknown. The volume of water in each waterhole is also likely to influence the probability of detection. At larger waterholes where numbers are below 100 individual Gouldian finches, collecting larger volumes and/or more samples may improve the detection probability.

Resources required for biodiversity surveys include labour, time, equipment, expertise and sample handling. eDNA sampling for target species may require as little as $200 \mathrm{ml}$ of water, and the approach we took cost approximately AUD 30 sample $^{-1}$ for processing or less with bulk samples (once the test developmental work had been done). As an alternative to waterhole surveys by direct observation, eDNA sampling is relatively quick, and can be done at any time of day; it is not confined to the short periods where birds come in to drink. This potentially allows a much larger 
number of waterholes to be systematically surveyed across the species' range.

In our study, water samples were filtered for DNA almost immediately, but this would be impractical if sampling across an extensive, remote area. Keeping samples cool and/or sent to a laboratory for DNA extraction within $72 \mathrm{~h}$ of collection is also not likely to be realistic. When we tested the effect of storing water for $14 \mathrm{~d}$ either cool or at room temperature, we found that the test results for the waterholes that gave high positive rates in the original test were still positive. Where there were low detection rates in the original test, the stored samples also gave low rates, albeit slightly better if stored cool. The negative controls where no birds were observed in the previous $72 \mathrm{~h}$ gave an occasional positive in the stored samples, which suggests that at very low concentrations the finch test can be positive, possibly reflecting residual DNA from previous visits by birds. This is not necessarily related to storage and is not likely to occur with the Gouldian finch test because of the internal DNA probe which provides both specificity and robustness. Our specific recommendations for routine eDNA detection of finches and Gouldian finches are to sample $200 \mathrm{ml}$ of water, preferably at observed drinking sites within $24 \mathrm{~h}$ of bird sighting. Where filtering on site is not feasible, water sample collection and cool storage for up to $14 \mathrm{~d}$ prior to lab processing is acceptable. Based on our results from the 'real-world' waterhole trials, a positive detection indicates that Gouldian finches have visited the area at least $48 \mathrm{~h}$ prior to water sampling. We recognise that the test may underestimate Gouldian finch absence/presence but we are confident that a correctly executed test will not give a false positive. An ongoing waterhole campaign is currently underway to refine some of these recommendations.

For this approach to be accepted as a successful adjunct or replacement survey method for the Gouldian finch, the technology and sampling protocols need to be effectively communicated to a range of research users. Once detection probability parameters are established, the next stage is to work in collaboration with research users to undertake coordinated waterhole sampling across the species' range using a standardised, robust sampling strategy. The approach must take into account the need to measure physical and physicochemical variables, including waterhole volume, temperature and turbidity. Broad-scale systematic monitoring is essential to provide reliable data to inform the conservation status of the Gouldian finch (Bolton et al. 2016) and the response of the species to land management activities, particularly fire.
Acknowledgements. We thank David Loewensteiner (Charles Darwin University, CDU), Andrea Crino (Deakin University), Paul Barden and Joanne Heathcote (EMS Consulting) for blood samples, which were collected under an Australian Research Council Linkage scheme awarded to H.C. at CDU. We also thank the Territory Wildlife Park Staff for facilitating the aviary research. We thank the Jawoyn Rangers, Ryan and Kenny, for $3 \mathrm{~d}$ of finch counts and water sampling. We thank the anonymous referees whose thorough reviews improved the manuscript. This project was supported through funding from the Australian Government's National Environmental Science Program, the Northern Territory Department of Environment and Natural Resources and CDU. Blood sampling was approved by the CDU Animal Ethics Committee (project number A17015), and collected under a Northern Territory Scientific permit (project number 61442).

\section{LITERATURE CITED}

Ahrberg CD, Neužil P (2015) Doubling throughput of a realtime PCR. Sci Rep 5:12595

Altschul SF, Gish W, Miller W, Myers EW, Lipman DJ (1990) Basic local alignment search tool. J Mol Biol 215:403-410

Anderson MJ, Gorley RN, Clarke KR (2008) PERMANOVA+ for Primer: guide to software and statistical methods. PRIMER-E, Plymouth

Bankevich A, Nurk S, Antipov D, Gurevich AA and others (2012) SPAdes: a new genome assembly algorithm and its applications to single-cell sequencing. J Comput Biol 19:455-477

Bolton PE, West AJ, Cardilini APA, Clark JA and others (2016) Three molecular markers show no evidence of population genetic structure in the Gouldian finch (Erythrura gouldiae). PLOS ONE 11:e0167723

Chung D (2004) The development of novel STR miniplex primer sets for the analysis of degraded and compromised DNA samples. PhD dissertation, Ohio University, Athens, $\mathrm{OH}$

Clarke KR, Somerfield PJ, Chapman MG (2006) On resemblance measures for ecological studies, including taxonomic dissimilarities and a zero-adjusted Bray-Curtis coefficient for denuded assemblages. J Exp Mar Biol Ecol 330:55-80

* Deagle BE, Eveson JP, Jarman SN (2006) Quantification of damage in DNA recovered from highly degraded samples - a case study on DNA in faeces. Front Zool 3:11

* Deiner K, Walser JC, Mächler E, Altermatt F (2015) Choice of capture and extraction methods affect detection of freshwater biodiversity from environmental DNA. Biol Conserv 183:53-63

*Dodsworth S (2015) Genome skimming for next-generation biodiversity analysis. Trends Plant Sci 20:525-527

* Dostine PL, Johnson GC, Franklin DC, Zhang Y, Hempel C (2001) Seasonal use of savanna landscapes by the Gouldian finch, Erythrura gouldiae, in the Yinberrie Hills area, Northern Territory. Wildl Res 28:445-458

Evans SM, Collins JA, Evans R, Miller S (1985) Patterns of drinking behaviour of some Australian estrildine finches. Ibis 127:348-354

Fukumoto S, Ushimaru A, Minamoto T (2015) A basin-scale application of environmental DNA assessment for rare endemic species and closely related exotic species in rivers: a case study of giant salamanders in Japan. J Appl Ecol 52:358-365

F Furlan EM, Gleeson D (2017) Improving reliability in environmental DNA detection surveys through enhanced quality control. Mar Freshw Res 68:388-395 
Jarman SN, Deagle BE, Gales NJ (2004) Group-specific polymerase chain reaction for DNA-based analysis of species diversity and identity in dietary samples. Mol Ecol 13:1313-1322

Jarman SN, Berry O, Bunce M (2018) The value of environmental DNA biobanking for long-term biomonitoring. Nat Ecol Evol 2:1192-1193

Kibbe WA (2007) OligoCalc: an online oligonucleotide properties calculator. Nucleic Acids Res 35:W43-W46

Langmead B, Salzberg SL (2012) Fast gapped-read alignment with Bowtie 2. Nat Methods 9:357-359

O'Malley C (2006) National recovery plan for the Gouldian finch (Erythrura gouldiae). WWF-Australia, Sydney, and Parks and Wildlife NT, Department of Natural Resources, Environment and the Arts, NT Government, Palmerston

Opel KL, Chung D, McCord BR (2010) A study of PCR inhibition mechanisms using real time PCR. J Forensic Sci 55:25-33

Piaggio AJ, Engeman RM, Hopken MW, Humphrey JS, Keacher KL, Bruce WE, Avery ML (2014) Detecting an elusive invasive species: a diagnostic PCR to detect Burmese python in Florida waters and an assessment of persistence of environmental DNA. Mol Ecol Resour 14: 374-380

Rodrigues ASL, Pilgrim JD, Lamoreux JF, Hoffmann M, Brooks TM (2006) The value of the IUCN Red List for conservation. Trends Ecol Evol 21:71-76

Saeki K, Sakai M (2009) The influence of soil organic matter on DNA adsorptions on andosols. Microbes Environ 24: 175-179

Takahara T, Minamoto T, Doi H (2013) Using environmental DNA to estimate the distribution of an invasive fish species in ponds. PLOS ONE 8:e56584

Thomas AC, Deagle BE, Eveson JP, Harsch CH, Trites AW (2016) Quantitative DNA metabarcoding: improved estimates of species proportional biomass using correction factors derived from control material. Mol Ecol Resour 16:714-726

Thompson JD, Gibson TJ, Higgins DG (2002) Multiple sequence alignment using ClustalW and ClustalX. Curr Protoc Bioinf Unit 2.3

*Thomsen PF, Willerslev E (2015) Environmental DNA - an emerging tool in conservation for monitoring past and present biodiversity. Biol Conserv 183:4-18

Thomsen PF, Kielgast J, Iversen LL, Wiuf C and others (2012) Monitoring endangered freshwater biodiversity using environmental DNA. Mol Ecol 21:2565-2573

Tidemann SC (1996) Causes of the decline of the Gouldian finch Erythrura gouldiae. Bird Conserv Int 6:49-61

Ushio M, Fukuda H, Inoue T, Makoto K and others (2017) Environmental DNA enables detection of terrestrial mammals from forest pond water. Mol Ecol Resour 17: e63-e75

Ushio M, Murata K, Sado T, Nishiumi I, Takeshita M, Iwasaki W, Miya M (2018) Demonstration of the potential of environmental DNA as a tool for the detection of avian species. Sci Rep 8:4493

Wilcox TM, McKelvey KS, Young MK, Jane SF, Lowe WH, Whiteley AR, Schwartz MK (2013) Robust detection of rare species using environmental DNA: the importance of primer specificity. PLOS ONE 8:e59520

Williams KE, Huyvaert KP, Piaggio AJ (2017) Clearing muddied waters: capture of environmental DNA from turbid waters. PLOS ONE 12:e0179282

*Williams KE, Huyvaert KP, Vercauteren KC, Davis AJ, Piaggio AJ (2018) Detection and persistence of environmental DNA from an invasive, terrestrial mammal. Ecol Evol 8:688-695

$\mathrm{Yu}$ WH, Li N, Tong DS, Zhou CH, Lin CXC, Xu CY (2013) Adsorption of proteins and nucleic acids on clay minerals and their interactions: a review. Appl Clay Sci 80-81: $443-452$

Appendix. PERMANOVA analyses

Table A1. PERMANOVA analyses for volume, first detection and persistence trials for detection of Gouldian finch eDNA. Perms: permutations; NS: not significant

\begin{tabular}{|c|c|c|c|c|c|}
\hline Data & Source & $\mathrm{df}$ & Pseudo- $F$ & Unique perms & $\mathrm{p}$ \\
\hline \multirow{3}{*}{ Minimum sample volume } & Aviary & 2 & 7 & 971 & 0.004 \\
\hline & Volume & 3 & 5.7 & 973 & 0.005 \\
\hline & Aviary $\times$ volume & 6 & 4.3 & 999 & 0.008 \\
\hline \multirow[t]{4}{*}{ First detection } & Visits & 1 & 36.4 & 801 & 0.001 \\
\hline & Aviary & 2 & 11.4 & 999 & 0.001 \\
\hline & Sample round & 6 & 3.3 & 999 & 0.006 \\
\hline & Aviary $\times$ sample round & 11 & 2.6 & 999 & 0.017 \\
\hline Persistence & Temperature & 1 & 13.15 & 347 & 0.001 \\
\hline 55 Gouldian finches & Aviary & 5 & 5.73 & 999 & 0.001 \\
\hline \multirow[t]{2}{*}{ Positive detection } & Sample round & 6 & 5.71 & 999 & 0.001 \\
\hline & Aviary $\times$ sample round & 26 & 1.93 & 998 & 0.008 \\
\hline Persistence & Treatment & 1 & 1.1 & 943 & $0.311(\mathrm{NS})$ \\
\hline Two Gouldian finchs & Sample round & 3 & 57.6 & 998 & 0.001 \\
\hline Positive detection & Treatment $\times$ sample round & 3 & 0.4 & 998 & 0.808 (NS) \\
\hline
\end{tabular}

Editorial responsibility: Mike Bruford, Cardiff, UK
Submitted: October 5, 2018; Accepted: August 30, 2019

Proofs received from author(s): October 30, 2019 